\title{
PENGARUH MOTIVASI DAN LINGKUNGAN KELUARGA TERHADAP MINAT BERWIRAUSAHA MAHASISWA (Studi Kasus Pada Mahasiswa Sekolah Tinggi Ilmu Sosial Dan Ilmu Politik Nurdin Hamzah Jambi)
}

\section{Joli Anggraeni}

Prodi Manajemen FEB Universitas Jambi joliangraeni70@gmail.com

\begin{abstract}
This study aims to determine the effect of variables of entrepreneurship motivation and family environment on student entrepreneur interest. (Case Study In High School Students Social Sciences And Political Sciences Nurdin Hamzah Jambi) The population in this study is a student of the College of Social and Political Science Nurdin Hamzah Jambi with 70 respondents. Data collection techniques used were questionnaires. Analyzer used in this research that is, test instrument consist of test of validity and reliability test, multiple linear regression analysis, $f$ test and t test and coefficient of determination test. The overall analysis was calculated using the SPSS ver 22 program. The results of this study indicate that the motivation of entrepreneurship and family environment has a positive and significant effect on entrepreneur interest.
\end{abstract}

Keywords: Entrepreneurship Motivation, Family Environment, Interest in Entrepreneurship.

\section{PENDAHULUAN}

\section{Latar Belakang}

Definisi kewirausahaan menurut Stevenson and Gumpert, (1983); O'Connorand Fiol, (2002)dalam Izedonme (2008) adalah sebuah proses identifikasi dalam kesempatan bisnis saat ini, dengan mengkombinasikan segala sumber daya dan kemudian mendirikan suatu usaha untuk melaksanakan kegiatan produksi dan mendistribusikan produk atau jasa tersebut yang berasal dari proses produksi.

Menurut Zuli Purnamawati (2009) menjadi pengusaha merupakan alternatif pilihan yang tepat. Paling tidak, dengan berwirausaha berarti menyediakan lapangan kerja bagi diri sendiri dan tidak bergantung pada orang lain. Seorang wirausahawan adalah seorang yang memiliki keahlian untuk menjual, mulai dari menawarkan ide hingga komoditas baik berupa produk ataujasa. Seorang wirausahawan (entrepreneur) adalah seseorang yang menciptakan bisnis baru dengan mengambil risiko dan ketidak pastian demi mencapai keuntungan dan pertumbuhan dengan cara mengidentifikasi peluang yang signifikan dan menggabungkan sumber-sumber daya yang diperlukan sehingga sumber-sumber daya itu bisa dikapitalisasikan (Zimmerer, 2008). Hasil penelitian Winda Syafitri, Dahmiri (2019) menyimpulkan bahwa faktor internal sangat mempengaruhi minat berwirausaha.

Jumlah pengangguran pada tahun 2016 (Data BPS, februari 2016) jumlah pengangguran pada Februari 2016 sebesar 79 ribu orang. Angka ini bertambah32,8 ribu orang dibandingkan Februari 2015. Melambatnya perekonomian Provinsi Jambi diiringi menurunnya minat penduduk usia produktif untuk aktif secara ekonomi. Penyerapan tenaga kerja sampai Februari 2016 masih didominasi oleh penduduk bekerja berpendidikan rendah yaitu SD ke bawah sebanyak 662,8 ribu orang (40,99\%) disusul SMA umum 310,9 ribu orang $(19,23 \%)$ dan SMP 309,7 ribu orang $(19,15 \%)$, bekerja dengan pendidikan 
SMA Kejuruan 114,5 ribu orang $(7,08 \%)$. Sementara itu pekerja berpendidikan tinggi sebanyak 219,3 ribu orang $(13,56 \%)$.

Salah satu penyebab kurang nya penyerapan tenaga kerja bagi yang sudah lulus kuliah atau sarjana ini adalah salah satunya karena banyaknya sarjana yang bertujuan hanya mencari pekerjaan, bukan menciptakan lapangan pekerjaan baru. Menjadi seorang wirausaha merupakan salah satu penentu maju atau mundurnya perekonomian, karena bidang wirausaha mempunyai kebebasan untuk berkarya dan mandiri (Oktarilis, 2012).

Motivasi berwirausaha merupakan dorongan terhadap serangkaian proses perilaku manusia pada pencapaian tujuan. Motivasi mempersilahkan seseorang untuk melakukan sesuatu sebab ia sendiri memang ingin melakukannya (Wibowo, 2013). Motivasi berasal dari kata latin movere yang berarti dorongan atau daya penggerak, motivasi ini hanya diberikan kepada manusia, khususnya kepada para bawahan atau pengikut. Berdasarkan beberapa pendapat di atas maka dapat diartikan bahwa motivasi adalah sesuatu kekuatan yang dapat mempengaruhi seseorang untuk melakukan sesuatu dengan ketekunan. Maka dapat disimpulkan bahwa motivasi berwirausaha adalah daya penggerak atau dorongan dalam diri yang menimbulkan semangat terhadap penciptaan suatu kegiatan atau pekerjaan dengan melihat peluang yang ada disekitar, bertindak berani dalam mengambil resiko, melakukan kegiatan yang inovatif, serta memiliki orientasi terhadap laba. Motivasi berwirausaha ini akan menentukan perilaku wirausaha dan selanjutnya secara tidak langsung menentukan kesuksesan bisnisnya (Sunyoto, 2013).

Seperti yang dilangsir dalam forum Pengusaha Muda Indonesia (2013), lingkungan merupakan faktor utama yang mempengaruhi perkembangan anak. Lingkungan bisa merupakan lingkungan keluarga maupun sekolah. Menurut Slameto (2010: 61-64) faktorfaktor lingkungan keluarga yang mempengaruhi perilaku anak yaitu: Cara orang tua mendidik, Relasi antaranggota keluarga, Suasana rumah, Keadaan ekonomi keluarga, Pengertian orang tua, Latar belakang kebudayaan.Berdasarkan faktor- faktor lingkungan keluarga yang mempengaruhi minat berwirausaha yang telah dipaparkan di atas, dapat dilihat beberapa hal yang dapat menentukan keberhasilan anak Jika anak selalu diajarkan untuk bekerja keras dan tidak hidup manja maka anak akan selalu bekerja keras untuk menggapai mimpinya. minat berwirausaha anak juga akan timbul jika keluarga menerapkan budaya berwirausaha terhadap anaknya. Anak akan lebih mengenal dan menyukai dunia wirausaha jika keluarga berasal dari keluarga yang menggeluti dunia wirausaha. Hal itu akan menjadi hal yang wajar karena anaksedari kecil telah terbiasa mengenal atau mengetahui bagaimana dan apa itu wirausaha.

Penelitian ini akan di lakukan di sekolah tinggi ilmu sosial dan ilmu politik (STISIP) Nurdin hamzah jambi adalah sebuah perguruan tinggi yang berada di bawah naungan yayasan dewi nurdin hamzah. Sebagai bagian daripenyelenggara pendidikan dalam bidang ilmu sosial dan politik, STISIP memiliki dua program studi yaitu program studi, studi kepemerintahan dan program studi ilmu komunikasi. Alumni STISIP nurdin hamzah jambi tersebar di dunia kerja, baik di birokrasi,lembaga negara, perusahaanperusahaan swasta, praktisi politik, konsultan komunikasi, reporter TV, wartawan media masa, dan wiraswasta.

Indonesia membutuhkan banyak lapangan pekerjaan, maka wirausaha sangat di butuhkan sehingga minat pada kewirausahaan baiknya bisa dapat ditumbuhkan berdasarkan motivasi dan linkungan keluarga dari sang anak, karena itulah maksud dari penelitian ini adalah ingin mengetahui bagaimanakah pengaruh faktor motivasi dan lingkungan keluarga terhadap minat berwirausaha. 


\section{Perumusan Masalah}

Apakah motivasi berwirausah dan lingkungan keluarga berpengaruh terhadap minat berwirausaha mahasiswa Sekolah Tinggi Ilmu Sosial Dan Politik Nurdin Hamzah Jambi ? Tujuan Penelitian

Untuk mengetahui pengaruh motivasi berwirausaha dan lingkungan keluarga terhadap minat berwirausaha mahasiwa Sekolah Tinggi Ilmu Sosial Dan Politik Nurdin Hamzah Jambi.

\section{TINJAUAN PUSTAKA \\ Motivasi Berwirausaha}

Daya penggerak/ dorongan dalam diri yang menimbulkan semangat terhadap penciptaan suatu kegiatan/ pekerjaan dengan melihat peluang yang ada disekitar, bertindak berani dalam mengambil resiko, melakukan kegiatan yang inovatif, serta memiliki orientasi terhadap laba. Motivasi berwirausaha ini akan menentukan perilaku wirausaha dan selanjutnya secara tidak langsung menentukan kesuksesan bisnisnya (Dan steinhoff \& John F. Burgess, 1993).

\section{Lingkungan Keluarga}

Keluarga merupakan kelompok sosial pertama dalam kehidupan manusiatempat belajar dan menyatakan diri sebagai manusia sosial di dalam hubunganinteraksi dengan kelompoknya. Dalam keluarga, seorang anak pertama-tamabelajar memperhatikan keinginan orang lain, bekerjasama, bantu membantu, atausebagai makhluk sosial dan mempunyai norma-norma dan kecakapan-kecakapantertentu dalam pergaulannya dengan orang lain (Sobur, 2003).

\section{Minat Berwirausaha}

Minat (interest) merupakan tingkat kegairahan yang menyertai perhatian khusus maupun terus menerus kepada suatu objek, peristiwa atau topik tertentu minat sangat dipengaruhi oleh dua variabel, yaitu: variabel sikap dan norma subyektif. Dengan kata lain, gabungan dari variabel sikap dan norma subyektif tidak akan langsung mempengaruhi perilaku, melainkan beroperasi terlebih dahulu melalui minat, dan minat inilah yang akan berpengaruh langsung pada perilaku (Setiawan, 2001).

\section{Hubungan Sikap Mandiri, Pengetahuan Kewirausahaan, dan Motivasi Berwirausaha Terhadap Intensi Wirausaha Mahasiswa}

Motivasi berwirausaha, dan lingkungan keluarga memiliki hubungan yang positif dan signifikan terhadap minat berwirausaha mahasiswa dengan nilai uji parsial masingmasing variabel yaitu variable motivasi berwirausah sebesar 3,691 untuk $t_{\text {hitung }}$ dengan sig. 0,000, variabel lingkungan keluarga sebesar 5,839 untuk $t_{\text {hitung }}$ dengan sig. 0,000. Hal ini menunjukkan bahwa semakin tinggi motivasi berwirausaha, dan lingkungan keluarga seorang mahasiswa maka semakin tinggi pula intensi berwirausaha yang ada di dalam dirinya.Di dukung oleh penelitian dari (Ari Widiyaningsih (2015) menyatakan hubungan yang positif dan signifikan antara Lingkungan keluarga dan motivasi berwirausaha terhadap minat berwirausaha.

\section{Hipotesis}

$\mathrm{Ha}$ : motivasi berwirausaha dan lingkungan keluarga secara simultan dan parsial berpengaruh positif dan signifikan terhadap minat berwirausaha mahasiswa.

Ho : motivasi berwirausaha dan lingkungan keluarga secara simultan dan parsial tidak berpengaruh positif dan signifikan terhadap intensi wirausaha mahasiswa. 


\section{METODE PENELITIAN}

\section{Pengambilan Sampel}

Menurut Sugiyono (2011), sampel adalah bagian dari jumlah dan karakteristik yang dimiliki oleh populasi. Sample merupakan bagian yang bergunabagi tujuan penelitian populasi dan aspek-aspeknya.

Populasi pada penelitian ini adalah mahasiswa STISIP jambi yang berjumlah 230 orang. Penentuan jumlah responden yang akan dibagikan kuesioner dengan menggunakan rumus Slovin

\section{HASIL PEMBAHASAN PENELITIAN Pengujian Validitas}

Pada penelitian ini banyaknya sampel sebesar $(n)=70$ dan besarnya $\mathrm{f}$ dapat dihitung $70-2=68$, dengan $\mathrm{df}=68$ dan alpha 0,05 di dapat $=0,235$. lebih besar dari dan nilai positif maka butir atau pertanyaan atau indikator tersebut dinyatakan valid. Dari tabel diatas terlihat bahwa secara keseluruhan indikator motivasi yang terdiri dari 8 indikator, lingkungan keluarga yang terdiri dari 6 indikator dan minat berwirausaha yang terdiri dari 6 indikator dinyatakan valid karena nilai corrected item-total correlation atau lebih besar dibandingkan 0,235. Tapi penelitian ini dapat dinyatakan valid karena yang dapat dilihat dari hasil statistik Corrected Item - Total Correlation lebih besar dari $r$ tabel.

\section{Pengujian Reliabilitas}

Berdasarkan hasil uji reliabilitas yang dilakukan dengan menggunakan program SPSS statistic versi 22, dapat disimpulkan bahwa variabel motivasi yang terdiri dari 8 indikator, lingkungan keluarga yang terdiri dari 6 indikator dan minat berwirausaha yang terdiri dari 6 indikator pernyataan lebih besar dari 0,70. Hal ini disimpulkan bahwa semua variabel penelitian ini berstatus reliabel. Maka penelitian dinyatakan reliable.

\section{Analisis Data}

Metode analisis data dalam penelitian ini menggunakan analisis regresi berganda. Dan menggunakan uji hipotesis yaitu uji $\mathrm{F}$ (simultan), uji t (parsial) dan uji koefisien determinasi.Adapun hasil analisis regresi berganda ditampilkan dalam tabel di bawah ini :

\section{Tabel 1. Hasil Regresi Berganda} Coefficients $^{\mathrm{a}}$

\begin{tabular}{|cl|l|l|l|}
\hline \multirow{2}{*}{\multicolumn{2}{c|}{ Model }} & \multicolumn{2}{|l|}{$\begin{array}{l}\text { Unstandardized } \\
\text { Coefficients }\end{array}$} & $\begin{array}{l}\text { Standardized } \\
\text { Coefficients }\end{array}$ \\
\cline { 2 - 5 } & \multicolumn{1}{|l|}{ B } & Std. Error & Beta \\
\hline $1 \quad$ ( C o n s t a n t ) & 4,098 & 2,218 &, 069 \\
M o t i v a s i &, 244 &, 066 &, 000 \\
LingkunganKeluarga &, 519 &, 089 &, 000 \\
\hline
\end{tabular}

a. Dependent Variable: minat ber wirausaha

Keterangan :

$$
\begin{aligned}
\mathrm{Y} & =\text { Minat Berwirausaha } \\
\mathrm{a} & =\text { Konstanta } \\
& =\text { Koefisien Regresi Motivasi Berwirausaha } \\
& =\text { Koefisien Regresi LingkunganKeluarga } \\
& =\text { Motivasi Berwirausaha } \\
& =\text { LingkunganKeluarga }
\end{aligned}
$$


Tabel 2. Hasil Analisis Uji F

ANOVA ${ }^{\mathrm{a}}$

\begin{tabular}{|ll|l|l|l|l|l|}
\hline \multicolumn{2}{|l|}{ Model } & Sum of & & & \\
\hline 1 & Squares & Df & Mean Square & F & Sig. \\
\hline & Regression & 331,887 & 2 & 165,939 & 43,613 &, $000^{\mathrm{b}}$ \\
& Residual & 254,923 & 67 & 3,805 & & \\
& Total & 586,800 & 69 & & & \\
\hline
\end{tabular}

a. Dependent Variable: MinatBerwirausaha

b.Predictors: (Constant), LingkunganKeluarga, Motivasi

Berdasarkan tabel terlihat bahwa nilai $\mathrm{F}_{\text {hitung }}$ sebesar 43,613 dengan p-value sebesar 0,000 dan nilai $F_{\text {hitung }}$ lebih besar dari nilai $F_{\text {tabel }}(43,613>3,13)$. Dengan demikian $\mathrm{H}_{\mathrm{a}}$ diterima. Dari hasil tersebut dapat dinyatakan bahwa secara simultan motivasi berwirausaha dan lingkungan keluargan berpengaruh terhadap minat berwirausaha mahasiswa pada sekolah tinggi ilmu sosial dan ilmu politik (STISIP) jambi.

Tabel 3. Hasil Analisis Uji t

Coefficients $^{\mathbf{a}}$

\begin{tabular}{|c|c|c|c|c|c|c|}
\hline \multirow{2}{*}{\multicolumn{2}{|c|}{ Model }} & \multicolumn{2}{|c|}{$\begin{array}{l}\text { Unstandardized } \\
\text { Coefficients }\end{array}$} & \multirow{2}{*}{ 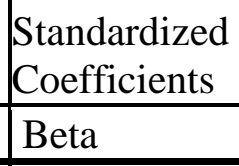 } & \multirow[b]{2}{*}{$\mathrm{t}$} & \multirow[b]{2}{*}{ Sig. } \\
\hline & & B & Std. Error & & & \\
\hline & (Constant) & 4,098 & 2,218 & & 1,848 & ,069 \\
\hline & Motivasi berwirausaha &, 244 & ,066 &, 337 & 3,691 &, 000 \\
\hline & Lingkungan keluarga &, 519 & 089 &, 533 & 5,839 &, 00 \\
\hline
\end{tabular}

a. Dependent Variable: minat berwirausaha

Uji ini digunakan untuk menjawab hipotesis pertama dan kedua ( dan . Pengujian dilakukan dengan membandingkan nilai dengan pada derajat kesalahan 5\% $(\alpha=0,05)$. Apabila >, maka variabel bebas memberikan pengaruh positif dan signifikan terhadap variabel terikat.

Penelitian ini dilakukan terhadap 70 orang responden $(n=70)$. Besaran derajat kebebasan (DK) dengan ketentuan $\mathrm{n}-2=70-2=68$. Dari ketentuan tersebut diperoleh data sebesar 1,667. Selanjutnya, untuk melihat besarnya pengaruh, digunakan angka Beta atau Standardized Coefficient (Jonathan Sarwono, 2007).

Tabel 4. Uji Koefisien Determinasi $\left(\mathbf{R}^{2}\right)$

Model Summary

\begin{tabular}{|l|l|l|l|l|}
\hline Model & $\mathrm{R}$ & R Square & $\begin{array}{l}\text { Adjusted R } \\
\text { Square }\end{array}$ & $\begin{array}{l}\text { Std. Error of the } \\
\text { Estimate }\end{array}$ \\
\hline 1 &, $752^{\mathrm{a}}$ &, 566 &, 553 & 1,951 \\
\hline
\end{tabular}

a. Predictors: (Constant), Motivasi Berwirausaha, Lingkungan keluarga

b. Dependen variabel : minat bewirausaha 
diperoleh nilai $\mathrm{R}$ square sebesar $0,566=56,6 \%$. Ini berarti variabel independen (motivasi berwirausaha dan lingkungan keluarga) secara bersama - sama mempengaruhi variabel dependen (minat berwirausaha) sebesar 56,6\% dan sisanya dipengaruhi oleh variabel lain yang tidak masuk dalam penelitian ini.

\section{PEMBAHASAN}

Menurut Fuadi (2009) minat berwirausaha adalah keinginan, ketertarikan, serta kesediaan untuk bekerja keras atau berkemauan keras untuk berusaha secara maksimal untuk memenuhi kebutuhan hidupnya tanpa merasa takut dengan resiko yang akan terjadi, serta berkemauan keras untuk belajar dari kegagalan. Minat wirausaha adalah gejala psikis untuk memusatkan perhatian dan berbuat sesuatu terhadap wirausaha itu dengan perasaan senang karena membawa manfaat bagi dirinya. Minat berwirausaha tidak dimiliki dengan begitu saja, melainkan dapat dikembangkan. peneliti melakukan penelitian mengenai pengaruh motivasi berwirausaha dan lingkungan keluarga terhadap minat berwirausaha mahasiswa pada Sekolah Tinggi Ilmu Sosial dan Ilmu Politik (STISIP) Jambi.

Berdasarkan rumusan masalah yang ada yaitu bagaimana pengaruh motivasi berwirausaha dan lingkungan keluargan terhadap minat berwirausaha mahasiswa pada sekolah tinggi ilmu sosial dan ilmu politik (STISIP) jambi. dari hasil uji analisis yang telah dilakukan penelitian ini menjawab bahwa secara simultan motivasi berwirausaha dan lingkungan keluarga berpengaruh positif dan signifikan terhadap minat berwirausaha mahasiswa pada sekolah tinggi ilmu social dan ilmu politik (STISIP) jambi. Kemudian secara parsial penelitian ini menjawab bahwasanya motivasi berwirausaha dan lingkungan keluarga berpengaruh positif dan signifikan terhadap minat berwirausaha mahasiswa pada sekolah tinggi ilmu social dan ilmu politik (STISIP) jambi dengan nilai uji parsial/ untuk motivasi berwirausaha nilai $(3,691>1,667)$. Selanjutnya variabel lingkungan keluarga dengan nilai $(5,839>1,667)$.

Hasil penelitian yang didapatkan sejalan dengan hasil penelitian terdahulu oleh Ari Widiyaningsih (2015) pengaruh Lingkungan Keluarga dan Motivasi Berwirausaha Terhadap Minat Berwirausaha Mahasiswa Program Studi Pendidikan Administrasi Perkantoran Fakultas Ekonomi UNY. Penelitian ini menunjukkan lingkungan keluarga dan motivasi berwirausaha secara bersama-sama berpengaruh terhadap minat berwirausaha mahasiswa Program Studi Pendidikan Administrasi Perkantoran Fakultas Ekonomi UNY. hasil penelitian yang penulis lakukan menunjukkan bahwa motivasi berwirausaha dan lingkungan keluarga berpengaruh terhadap minat berwirausaha. Pengaruh tersebut sebesar $33,7 \%$ untuk motivasi berwirausaha dan 53,3\% untuk lingkungan keluarga.

\section{KESIMPULAN}

Terbukti bahwa secara simultan motivasi berwirausaha dan lingkungan keluarga berpengaruh positif dan signifikan terhadap terhadap minat berwirausaha pada Sekolah Tinggi Ilmu Sosial dan Ilmu Politik (STISIP) Jambi. Sedangkan secara parsial motivasi berwirausaha dan lingkungan keluarga berpengaruh positif dan signifikan terhadap terhadap minat berwirausaha pada Sekolah Tinggi Ilmu Sosial dan Ilmu Politik (STISIP) Jambi dengan nilai uji parsial untuk motivasi berwirausaha dengan nilai (3,691> 1,667)dan nilai signifikan 0,000. Artinya motivasi berwirausaha memberikan pengaruh yang positif dan signifikan terhadap minat berwirausaha padaSekolah Tinggi Ilmu Sosial dan Ilmu Politik (STISIP) Jambi. Besarnya pengaruh motivasi berwirausaha secara parsial terhadap minat berwirausaha adalah 0,337 atau $33,7 \%$. Artinya motivasi berwirausaha mampu mempengaruhi minat berwirausahahanya sebesar $33,7 \%$. 
Lingkungan keluarga dengan nilai $(5,839>1,667)$ dengan nilai signifikan 0,000 . Artinya lingkungan keluarga memberikan pengaruh yang positif dan signifikan terhadap minat berwirausaha pada Sekolah Tinggi Ilmu Sosial dan Ilmu Politik (STISIP) Jambi.

Besarnya pengaruh lingkungan keluarga secara parsial terhadap minat berwirausaha adalah 0,537 atau 53,7\%. Artinya lingkungan keluarga mampu mempengaruhi minat berwirausaha sebesar $53,7 \%$.

Selanjutnya, jika dilihat dari analisis Uji Koefisien Determinan (R Square), secara bersama - sama variabel motivasi berwirausaha dan lingkungan keluarga berpengaruh terhadap minat berwirausaha hanya sebesar 56,6\%. Sedangkan sisanya dipengaruhi oleh variabel lainnya yang tidak termasuk dalam penelitian ini.

\section{DAFTAR PUSTAKA}

Aditya Dion Mahesa. 2012. Analisis Faktor-Faktor Motivasi yang Mempengaruhi Minat Berwirausaha. Pada Mahasiswa S1 Fakultas Ekonomika Dan Bisnis Universitas Diponegoro Semarang. Tesis Fakultas Ekonomika Dan Bisnis

Edi Hardum. (2015). Menghadapi MEA, Indonesia Dituntut Genjot Jumlah Wirausaha. Diakses dari http://bisnis.news.viva.co.id/news/read/599530-jumlah-wirausaha-ritak-sebanding-dengan-tingginya-minat. Pada tanggal 18 Januari 2017, jam 10.30 WIB.

Yandi Mohammad. (2015). Data BPS: Pengangguran di Indonesia 7,56 JutaOrang.Diakses dari http://www.cnnindonesia.com. Pada tanggal tanggal 18 Januari 2017, jam 10.45 WIB.

Leonardus Saiman. (2009). Kewirausahaan, Teori, Praktik, dan Kasus-kasus.Jakarta: Salemba

Martin Handoko. 2003. Motivasi Penggerak Tingkah Laku. Yogyakarta: Kanisius.

Eka Aprilianty. 2012. Pengaruh Potensi Kepribadian Wirausaha, Pengetahuan Kewirausahaan, dan Lingkungan terhadap Minat Berwirausaha Siswa SMK Rumpun Pertanian di Daerah Istimewa Yogyakarta. Tesis. UNY.

Sjarkawi. 2008. Pembentukkan Kepribadian Anak. Jakarta: Bumi Aksara.

Slameto. 2010. Belajar dan Faktor-faktor yan Mempengaruhinya. Jakarta: PT.Rineka Cipta.

Sugiyono. 2009. Metode Penelitian Kuantitatif, Kualitatif dan R\&D. Bandung:Alfabeta.

Sujanto, Agus., Halem Lubis, dan Taufik Hadi. 2006. Psikologi Kepribadian.

Winda Syafitri, Dahmiri (2019). Pengaruh Faktor Internal Terhadap Minat Berwirausaha Mahasiswa Fakultas Ekonomi Dan Bisnis Universitas Jambi. Jurnal Manajemen Terapan dan Keuangan. Vol. 8 (1). 1-12. 